\title{
Eulophia euglossa newly recorded for Kenya and Tanzania
}

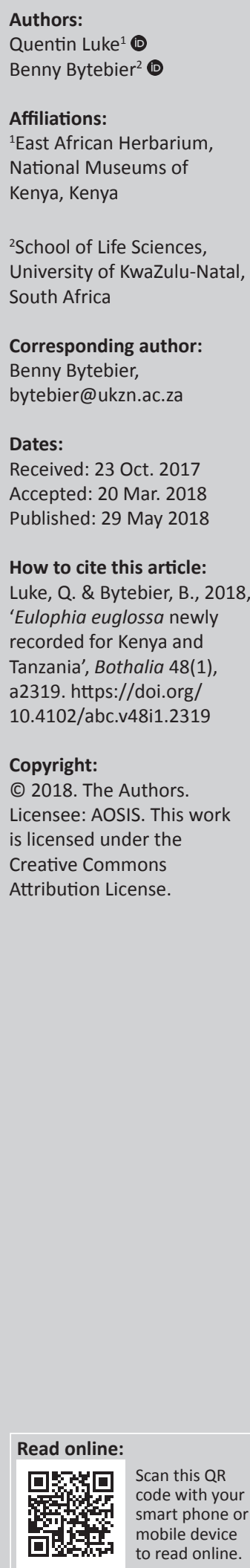

Background: The orchid flora of East Africa is well documented. Nevertheless, new country records are still being discovered.

Objectives: To further document the orchid flora of East Africa.

Method: Herbarium collections and databases were studied. Relevant published literature was consulted.

Results: Eulophia euglossa is newly recorded for Kenya and Tanzania.

Conclusion: The newly recorded species increases our understanding of the orchid diversity in East Africa and underlines the need for continued botanical inventories.

\section{Introduction}

The orchid flora of East Africa, and of Kenya specifically, is well documented (Cribb 1984, 1989; Piers 1968; Stewart 1996; Summerhayes 1968). Nevertheless, new species as well as new country records are regularly added and thus floristic treatments need occasional revision. During the XXI AETFAT (Association for the Taxonomical Study of the Flora of Tropical Africa) meeting held in Nairobi in May 2017, the botanical community was informed of a new collaborative project between the Chinese Academy of Sciences and the East African Herbarium (EA) to produce a new 'Flora of Kenya' (G. Mwachala [East African Herbarium], pers. comm., May 2017). In view of this initiative, it is important to document new country records and findings so that they can be easily referenced and integrated in the future floras.

The terrestrial orchid genus Eulophia R.Br. ex Lindl. is morphologically extremely diverse and occupies a surprisingly wide variety of habitats, from semi-arid regions and coastal dunes to swamps, and from grasslands to tropical forests, but is most diverse in the miombo woodlands of south-central Africa (la Croix \& Cribb 1998; Williamson 1977). Over 170 species of Eulophia are currently accepted of which more than 120 are distributed over sub-Saharan Africa and the Western Indian Ocean Islands, undoubtedly their centre of diversity (Martos et al. 2014).

Eulophia sensu lato was shown to be paraphyletic and was therefore split into two genera Eulophia sensu stricto and Orthochilus A.Rich. (Martos et al. 2014). A comprehensive monographic treatment of Eulophia, with an evolutionary meaningful infra-generic classification, is still needed, particularly in view of the fact that many species are widespread and show considerable regional variation. Fortunately, several regional treatments, such as the one for Tropical East Africa (Cribb 1989), have already been prepared.

Here we report on Eulophia euglossa, a species that is widespread in West Africa and has been documented in Tropical East Africa for Uganda (U4), but has not been recorded in Kenya and Tanzania (Cribb 1989; Piers 1968; Stewart 1996).

In the course of 2016, one of us (Q.L.) collected an orchid specimen near Bungoma in Kenya (Luke 18008; Figure 1), which was later identified as Eulophia euglossa (Rchb.f.) Rchb.f. ex Bateman on the basis of the key in the Flora for Tropical East Africa (FTEA) - Orchidaceae Part 3 (Cribb 1989). The long internodes between the pseudobulbs and the green flowers with a white lip marked with a transverse pink to purple band across the base of the midlobe (Figure 1) are quite diagnostic. The specimen matches the description and figure in Bateman (1866), as well as the photographs in Perez-Vera (2003). Furthermore, the first author was familiar with this species as he had collected a specimen in a forest patch near Nabugabo (U4) on 14 April 2016 (Luke WRQ, Maunder M, Beentje $H \mathcal{E}$ Luke PA 17208). The first author (together with Beentje \& Munderi) also recorded a possible specimen of this taxon in the Zika Forest near Entebbe on 23 April 2017, although it was sterile. 


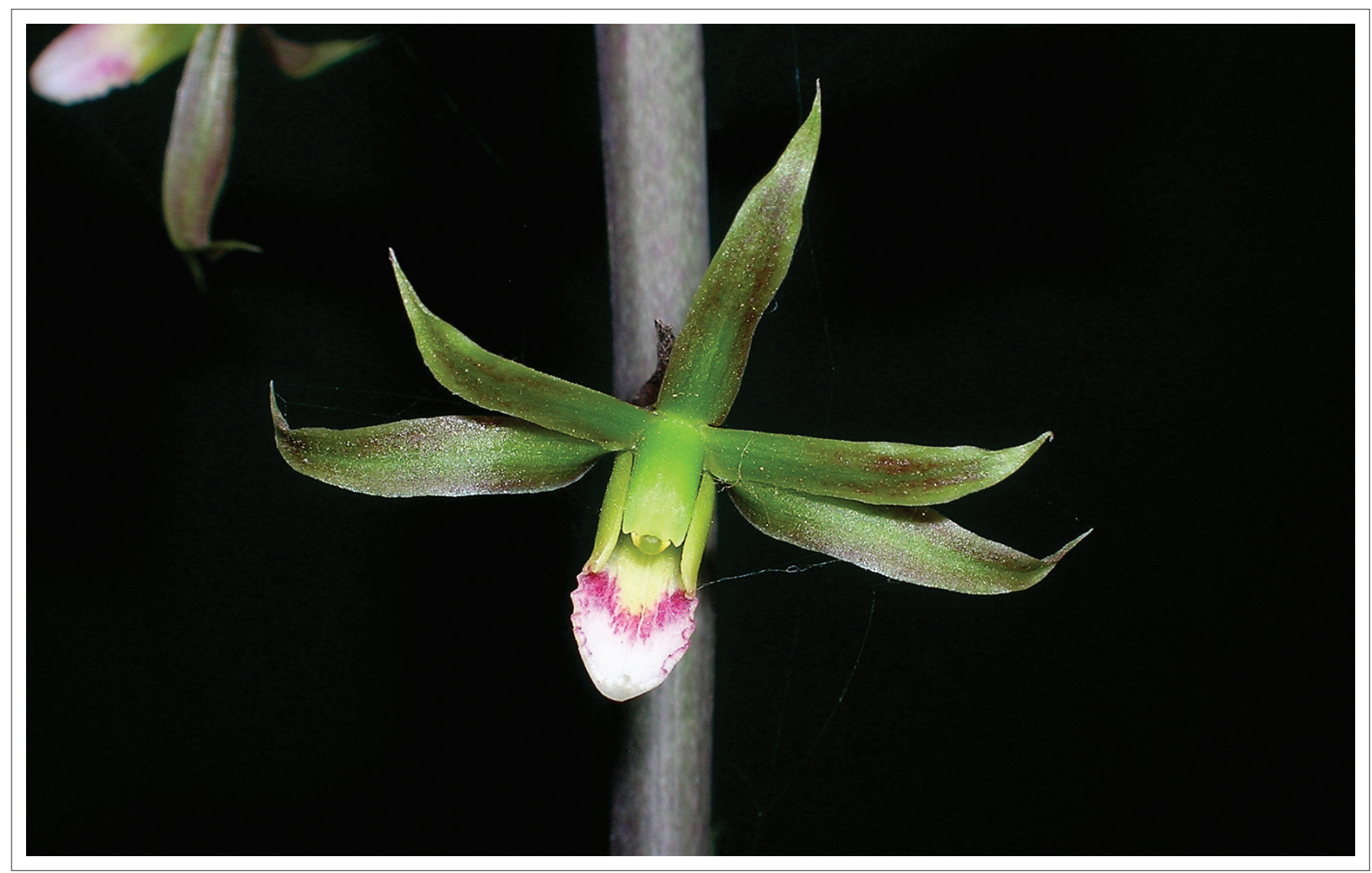

Source: Photo taken by Quentin Luke

FIGURE 1: Eulophia euglossa, Luke 18008 (Kenya).

The ID was confirmed by the second author (B.B.), who remembered receiving a living specimen of this species in 1999 from Prof. N. Olembo of the Biochemistry Department, University of Nairobi. As this specimen came from transformed, agricultural land near Kakamega (Kenya), human introduction, although unlikely, could not be excluded and the find was not reported in the literature. The second find of the species by Q.L. confirms that it occurs naturally in Kenya.

Consultation of the orchid specimen database of the East African Herbarium (EA) and Missouri Botanical Garden (Tropicos) revealed three more specimens from Tanzania, another country for which the distribution of this species had not been recorded in FTEA. Further confirmation that it occurs there come from an unpublished checklist of Minziro Forest Reserve (T1), in which this taxon is cited (K. Vollesen [Royal Botanic Gardens Kew], pers. comm. to Q.L., 2017).

Eulophia euglossa is usually found in 'dense forest of Uapaca guineensis Müll.Arg., Harungana madagascariensis Lam. ex Poir., Maesopsis eminii Engl., and so on, on red-brown sandy loam over ironstone, also in secondary forest, $1200 \mathrm{~m}-1300 \mathrm{~m}$ (Cribb 1989). The Kenyan specimen was found growing amongst riverine, scrubby vegetation at $1360 \mathrm{~m}$ near Bungoma town, along the Sio River, during an Environmental Impact Assessment (EIA) survey prior to the damming of the river. Woody plants found in association with it were:
Combretum paniculatum Vent., Garcinia buchananii Baker, Grewia trichocarpa Hochst. ex A.Rich., Entada abyssinica A.Rich., Trimeria grandifolia (Hochst.) Wrab. and Rauvolfia caffra Sond. Several exotic species were also noted such as Caesalpinia decapetala (Roth) Alston, Artocarpus heterophyllus Lam., Cascabela thevetia (L.) Lippold and Jacaranda mimosifolia D.Don probably owing to the proximity of the town and the degree of conversion of the natural vegetation.

\section{Taxonomic treatment}

Eulophia euglossa (Rchb.f.) Rchb.f. ex Bateman, Bot. Mag. 92: t. 5561 (1866). Galeandra euglossa Rchb.f., Bot. Zeitung (Berlin) 10: 935 (1852). Type: ex SIERRA LEONE, cult Van Hees (W, holo [not seen]).

=Eulophia dusenii Kraenzl., Bot. Jahrb. Syst. 19: 254 (1894). Type: CAMEROUN, Dusen 264 (B, holo†; K, drawing [not seen])

\section{Distribution}

22 GHA IVO LBR NGA SIE TOG 23 CAF CMN GAB ZAI 24 ETH 25 UGA 26 ANG (WCSP 2017). Here extended to 25 KEN, TAN (Figure 2).

\section{Specimens examined}

KENYA - K5 (Nyanza), Bungoma, near Bungoma town along the Sio River, $0^{\circ} 32^{\prime} 03^{\prime \prime} \mathrm{N}, 34^{\circ} 30^{\prime} 33^{\prime \prime} \mathrm{E}, 1360 \mathrm{~m}$, 23 Sept. 


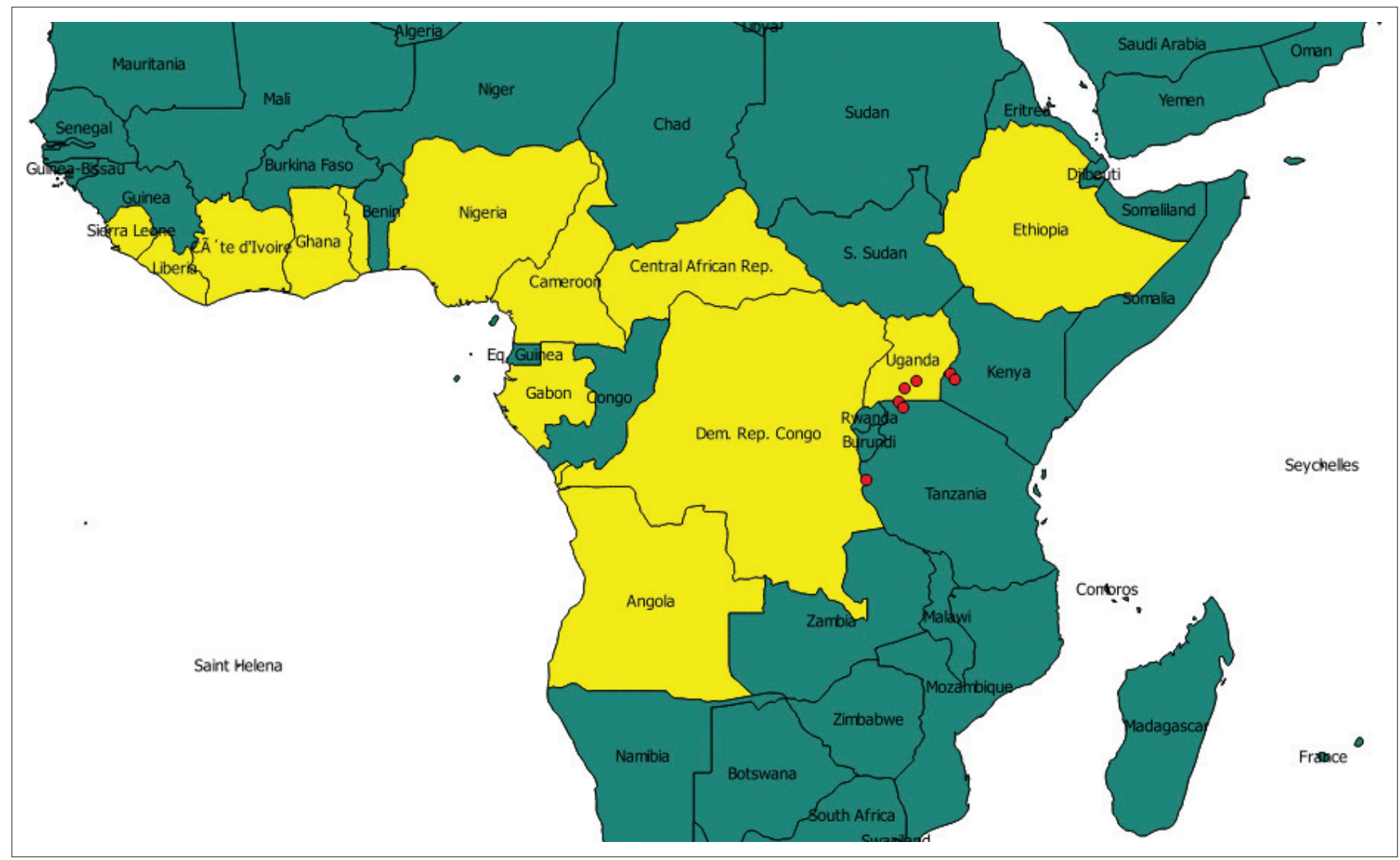

Source: Map created by Quentin Luke

FIGURE 2: Distribution map of Eulophia euglossa. Countries where this species has previously been recorded are in yellow. Red dots represent new records mentioned in this article.

2016, Luke 18008 (EA; OrchidMap: http://vmus.adu. org.za/?vm=OrchidMAP-6294); Kakamega, Ikolomani, Shisheno, a few $\mathrm{km}$ from Kakamega town on the KakamegaKisumu road at the home of Prof. Norah Olembo's mother. $00^{\circ} 09^{\prime} \mathrm{N}, 34^{\circ} 45^{\prime} \mathrm{E}, 1500 \mathrm{~m}, 15$ Oct. 1999, Bytebier 1722 (EA, BR).

TANZANIA - T1 (Lake), Bukoba, Rubare Forest Reserve, 012ㄱ'S, 31ํ⒏5'E, 4000 feet, Jan. 1958, Proctor 781 (EA, TFD); Kagera, Bukoba Rural, Minziro Forest Reserve, Sinje, Kagera River, near forest margin, $01^{\circ} 04^{\prime} 03^{\prime \prime} \mathrm{S}, 031^{\circ} 35^{\prime} 57^{\prime \prime} \mathrm{E}^{\prime}, 1120 \mathrm{~m}$, 22 Dec. 2000, Festo E Bayona 857 (MO); T4 (Western), Kigoma, Kabogo Mountains, $05^{\circ} 28^{\prime} \mathrm{S}, 2^{\circ} 45^{\prime} \mathrm{E}, 950$ m, 30 Nov. 1962, Kyoto University Expedition 306 (EA).

\section{Acknowledgements}

The National Research Foundation (NRF) of South Africa financially supports the research of B.B.

\section{Competing interests}

The authors have no competing interests.

\section{Authors' contributions}

Q.L. and B.B. identified the material and wrote the article.

\section{References}

Bateman, J., 1866, 'Eulophia euglossa', Botanical Magazine 92, tab 5561, viewed September 2017, from https://www.biodiversitylibrary.org/item/14368\#page/42/ mode/1up

Cribb, P., 1984, 'Orchidaceae Part 2', in R.M. Polhill (ed.), Flora of Tropical East Africa, pp. 237-411, Published on behalf of the East African Governments by A.A. Balkema, Rotterdam.

Cribb, P., 1989, 'Orchidaceae Part 3', in R.M. Polhill (ed.), Flora of Tropical East Africa, pp. 413-651, Published on behalf of the East African Governments by A.A. Balkema, Rotterdam.

la Croix, I. \& Cribb, P.J., 1998, 'Eulophia', in G.V. Pope (ed.), Flora Zambesiaca, Vol. 11 Part 2, pp. 458-537, Royal Botanic Gardens, Kew.

Martos, F., Johnson, S.D., Peter, C.I. \& Bytebier, B., 2014, 'A molecular phylogeny reveals paraphyly of the large genus Eulophia (Orchidaceae): A case for the reinstatement of Orthochilus', Taxon 63, 9-23. https://doi.org/10.12705/631.6

Perez-Vera, F., 2003, Les Orchidées de Cote d'lvoire, Collection Parthenope, Mèze. Piers, F., 1968, Orchids of East Africa, Verlag von J. Cramer, Lehre.

Stewart, J., 1996, Orchids of Kenya, St Paul's Bibliographies, Winchester.

Summerhayes, V.S., 1968, 'Orchidaceae Part 1', in E. Milne-Redhead \& R.M. Polhill (eds.), Flora of Tropical East Africa, pp. 1-235, Crown Agents for Oversea Governments and Administrations, London.

Williamson, G., 1977, The Orchids of South Central Africa, J.M. Dent, London.

World Checklist of Selected Plant Families (WCSP), 2017, Facilitated by the Royal Botanic Gardens, Kew, viewed September 2017, from http://apps.kew.org/wcsp/ 